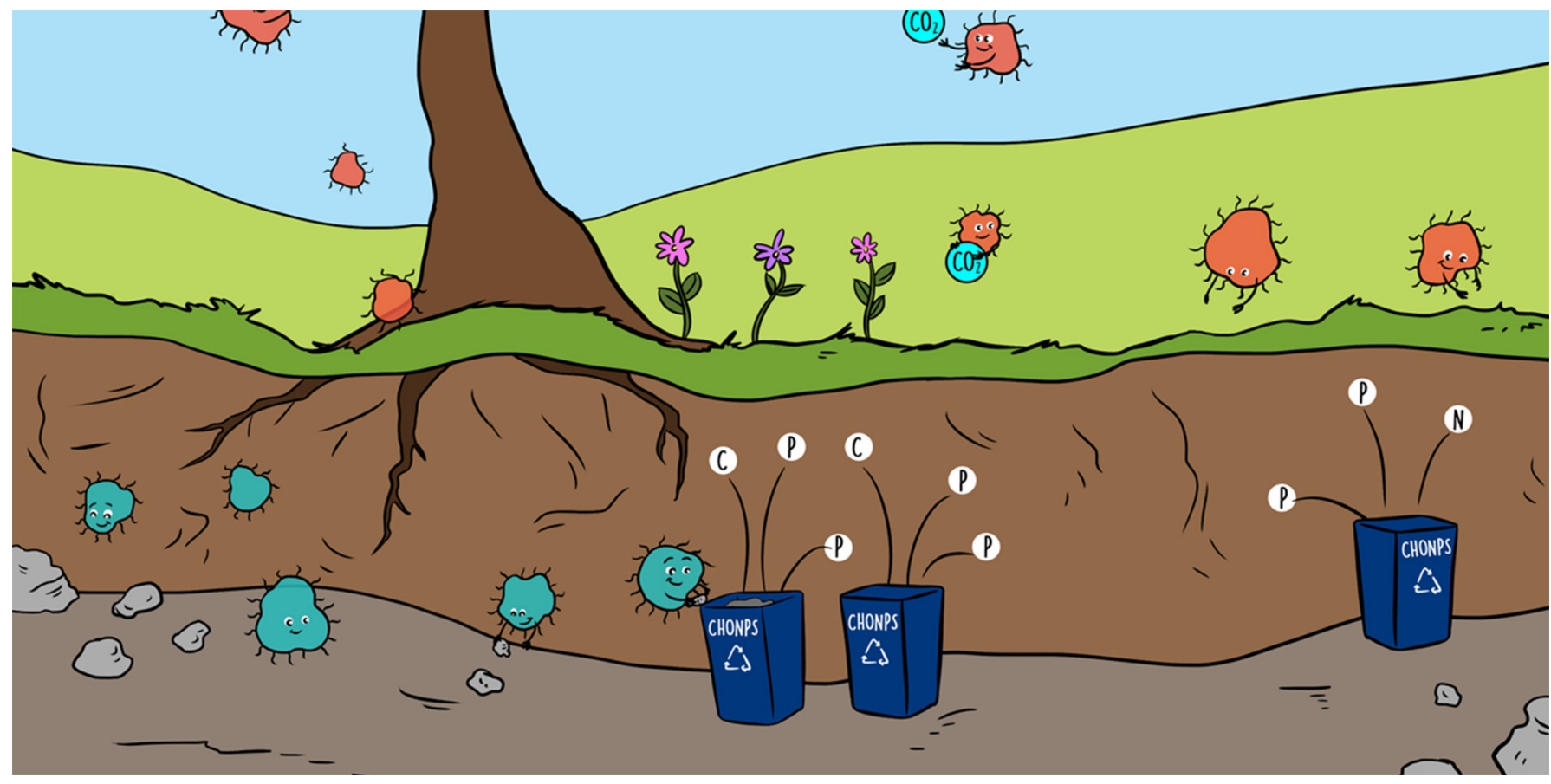

\title{
BACTERIA HAVE SUPERPOWERS TO RECYCLE SOIL NUTRIENTS
}

\section{Yunuen Tapia-Torres * and Alberto Morón-Cruz}

Escuela Nacional de Estudios Superiores unidad Morelia, Universidad Nacional Autónoma de México, Morelia, Mexico

YOUNG REVIEWERS:

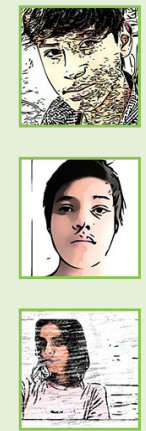

ALAN

AGE: 13

DIEGO

AGE: 14

MANU

AGE: 14

\section{BIOMOLECULE}

Molecules that make up all living beings, including proteins, carbohydrates, nucleic acids, and phospholipids.
Bacteria are everywhere, and they do not only cause diseases! Bacteria are also involved in many processes that are indispensable for our life on Earth. Many of these processes have to do with the recycling (reuse) of chemical elements that have been here since the formation of the planet. Bacteria play an important role in the movement of the chemical elements between air, water, soil, and living things, allowing life as we know it to evolve. How do bacteria recycle chemical elements so that we can use them? Through important superpowers coded for by their genes!

\section{THE CHEMISTRY OF LIFE}

All living organisms we know of today are made of biomolecules (proteins, carbohydrates, nucleic acids, and phospholipids) that are composed of a group of important chemical elements. In the formation of biomolecules, some chemical elements are needed in large quantities; they are known as macroelements. The macroelements are carbon $(\mathrm{C})$, hydrogen $(\mathrm{H})$, oxygen $(\mathrm{O})$, nitrogen 
Figure 1

The movement of important molecules containing carbon, nitrogen, and phosphorus through an ecosystem. Boxes represent the nutrient pools (with the names of the compounds and their chemical formulas) and arrows represent processes. The names of some of the bacteria that perform various processes are listed beside the arrows.

\section{PROTEINS}

The building blocks of every cell in living beings. Proteins are critical for the chemical reactions of metabolism and they also give cells their structure.

\section{MACROELEMENT}

A chemical element required in large quantities for the normal physiological processes of living organisms.

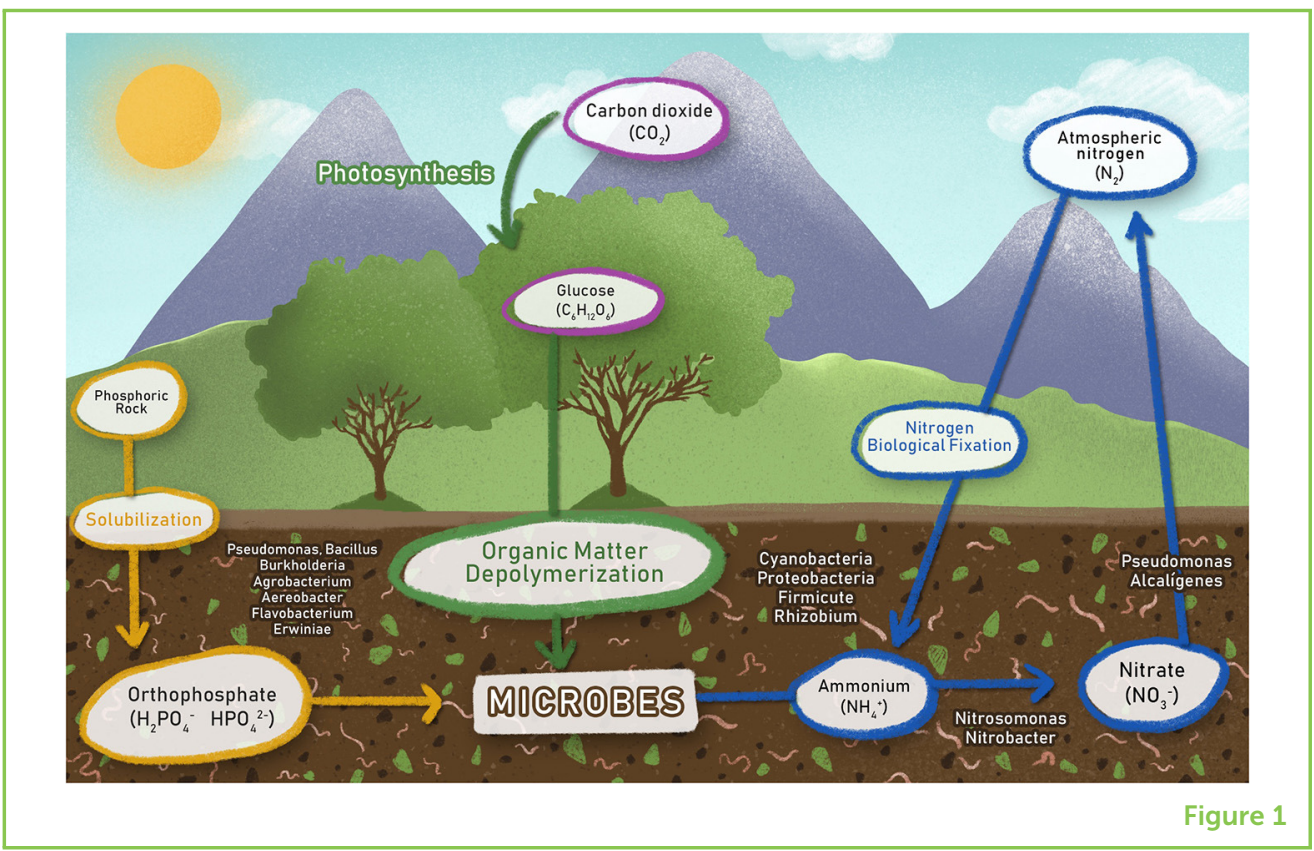

$(\mathrm{N})$, phosphorus $(\mathrm{P})$, and sulfur $(\mathrm{S})$, which we abbreviate as CHONPS. These 6 elements are the main constituents of our cells and represent $95 \%$ of the total biomass (all the matter contained in living beings) on the planet. All elements found naturally on Earth are very old; they are approximately the same age as the planet (4.5 billion years). Can you imagine that? The same CHONPS atoms have been part of the different molecules of many living beings on the Earth again and again, through a process of biological recycling. This means that all the atoms that form our bodies are the same atoms that could have been part of the dinosaurs millions of years ago! This is amazing!

Atoms of the macroelements can join together to form different molecules. Oxygen can join with hydrogen to make water $\left(\mathrm{H}_{2} \mathrm{O}\right)$ or it can join with carbon to make carbon dioxide $\left(\mathrm{CO}_{2}\right)$. On Earth, large amounts of macroelements are found in the atmosphere as gases. Maybe you have heard of $\mathrm{CO}_{2}$, molecular oxygen $\left(\mathrm{O}_{2}\right)$, and molecular nitrogen $\left(\mathrm{N}_{2}\right)$, for example. These are examples of gaseous molecules containing macroelements. In contrast, elements, such as $\mathrm{N}$ can be found forming different molecules in the air, water, and soil. However, other macroelements, such as $\mathrm{P}$, do not exist as gases, but we find them in the soil and water (Figure 1).

\section{HOW CAN AN ELEMENT MOVE THROUGHOUT THE ECOSYSTEM?}

The movement of the macroelements (CHONPS) within the soil, water, and atmosphere depends mainly on the activity of microscopic organisms: the microbes. "Microbe" refers to a living thing too small to be seen with the naked eye, and this term is used to describe 
Figure 2

Different ways by which CHONPS move between the air, living things, and soil are shown. Plants and animals incorporate soil organic matter rich in CHONPS; i.e., excrements of animals and leaves that fall from trees. Soil bacteria perform recycling of soil organic matter through different processes, and as a result they produce and release into the soil inorganic molecules $\left(\mathrm{NH}_{4}^{+}, \mathrm{NO}_{3}^{-}, \mathrm{PO}_{4}^{3-}\right.$, $\mathrm{CO}_{2}$ ) that can be consumed by plants and microorganisms to grow and perform their functions. Without the presence of soil microorganisms, CHONPS contained in soil organic matter cannot be reused and ecosystems could no longer function. The boxes represent the nutrient pools, black arrows represent microbial processes, and blue arrows represent processes in which microbes do not participate.

\section{GENE}

A piece of DNA that encodes the instructions for making a protein.

\section{BIOLOGICAL NITROGEN FIXATION}

The process in which nitrogen gas $\left(\mathrm{N}_{2}\right)$ is incorporated into the biomass of living organism and converted to organic nitrogen.

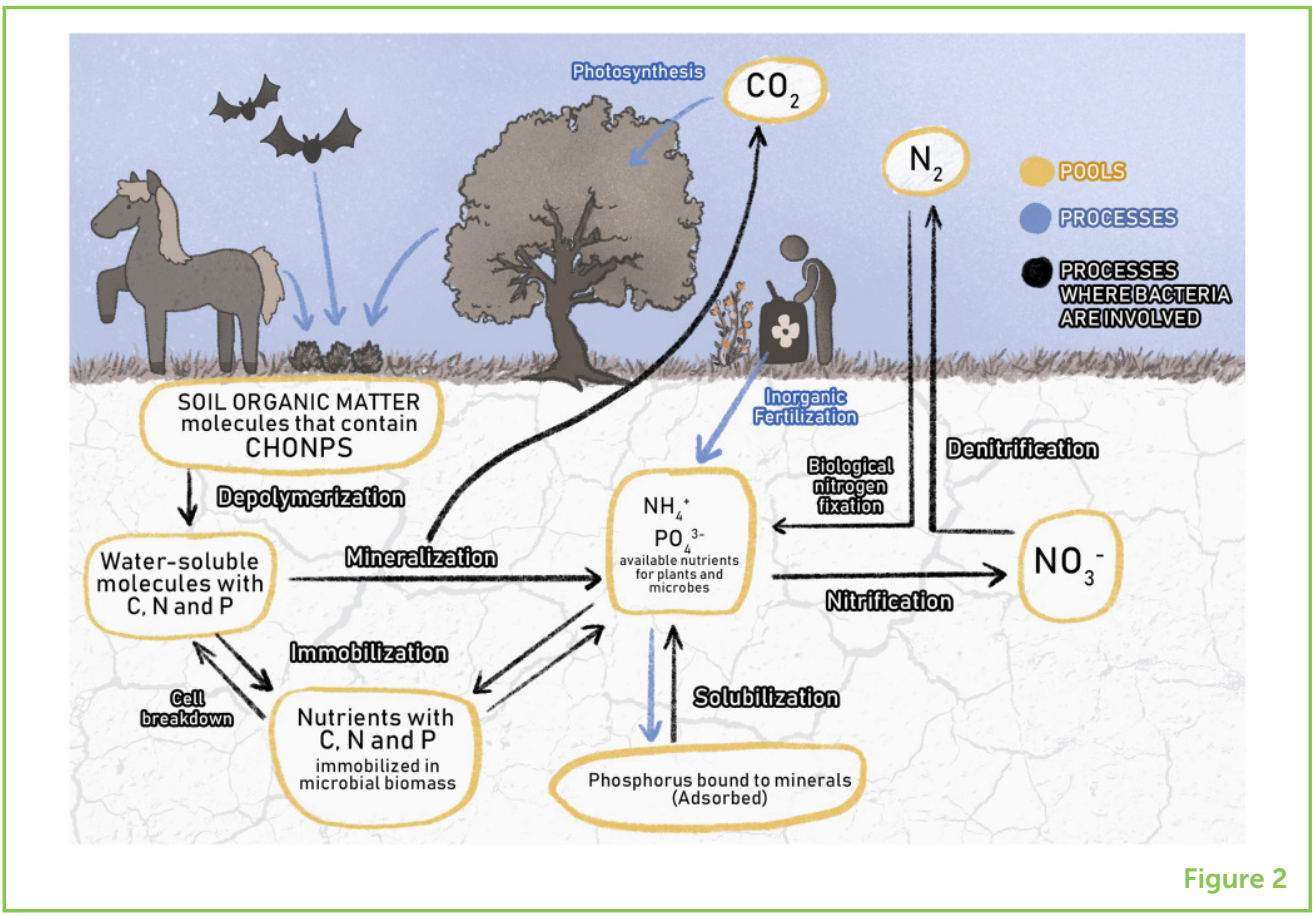

several very different life forms (bacteria, fungi, archaea, viruses, and protists).

Bacteria are responsible for the recycling and transformation of elements on Earth and they perform this task thanks to the superpowers encoded in their genes. Genes are the instructions for making the molecules that are needed for many different processes, including the recycling of macroelements. For example, through a process called biological nitrogen fixation (Figure 1), bacteria can use $\mathrm{N}$ molecules in gaseous form $\left(\mathrm{N}_{2}\right)$ to make proteins, which are solid organic molecules rich in $\mathrm{C}$ and $\mathrm{N}$. This is extraordinary: bacteria are the only living organisms that can convert, through chemical reactions regulated by genes, gaseous $\mathrm{N}_{2}$ into proteins that help them to grow and sustain their lives! Humans cannot use $\mathrm{N}_{2}$ the way bacteria do, but thanks to these bacteria we can also have proteins (and therefore N) in our bodies. Therefore, the chemical elements can go from being in the atmosphere to dissolved in water existing in the soil, or from being in the form of a gas to being inside a living organism (Figures 1, 2). All of these transformations occur thanks to bacterial activity.

Some of the processes used for recycling and transformation of macroelements that form biomolecules are shown in Figure 2. Each arrow indicates a process regulated by different species of soil bacteria, and each box represents a pool of nutrients for soil bacteria and other soil microbes.

To understand Figure 2, think of the leaves that fall from the trees in the forest. These leaves accumulate in the soil and form a layer of organic matter (OM; a mixture of biomolecules). The $O M$ is made up 


\section{DEPOLYMERIZATION}

The process of converting a big molecule (polymer) into a small molecule (monomer) or a mixture of small molecules.

\section{MINERALIZATION}

A biological process in which organic molecules are converted into inorganic molecules.

\section{IMMOBILIZATION}

Processes carried out by microorganisms and plants where they incorporate inorganic molecules into their biomass and convert them into organic molecules. of different kinds of waste from plants and animals and contains very large molecules with CHONPS in them. These large molecules are difficult for plants to use, because they are so big. So, the soil microbes break down the OM molecules into small pieces. The process of breaking down OM molecules is called depolymerization, and it results in a set of small molecules that can dissolve in water, such as glucose (Figure 2). These dissolved compounds are very important for the soil microbes that consume them, because they are the microbes' source of $C$.

\section{HOW DO BACTERIA TRANSFORM THE ELEMENTS THAT ARE ONLY PRESENT IN SOIL AND WATER?}

Phosphorus does not have a stable gaseous form. Therefore, we cannot find it in the atmosphere; rather, we can find $P$ in the rocks of the Earth's crust. $P$ is essential for all living beings because it is in many biomolecules, including DNA. P is also widely used as fertilizer in food production. But... how do living organisms acquire $P$ if they do not eat rocks? Bacteria are primarily responsible for $P$ recycling in nature, and they regulate the pool of available $\mathrm{P}$ (in the form of phosphate; $\mathrm{PO}_{4}^{3-}$ ) through a variety of $\mathrm{P}$-transformation processes ( $\mathrm{P}$ solubilization, $\mathrm{OM}$ depolymerization, $P$ mineralization, and $P$ assimilation; Figure 2). Later, plants acquire $P$ from the soil, herbivores acquire it when they eat the plants, and carnivores when they eat the herbivores. In this way, animals can use the $P$ originally found in the rocks to build their bodies.

We know of about 200 different molecules that contain P, and each of these molecules can be the food for a different bacterial group. Can all bacteria use all the different P-containing molecules? To answer this question, we performed an experiment. We isolated 1,163 kinds of bacteria from the soil and sediment of an ecosystem with little $P$ available. We evaluated these bacteria for their ability to use the $\mathrm{P}$ contained in six different $\mathrm{P}$-containing molecules (Figure 3). To be able to use and immobilize the $P$ contained in each of these molecules, bacteria need different genes to carry out different processes (Figure 2).

To understand this experiment, imagine P-hungry soil bacteria in each of the Petri dishes in Figure 3A. All the Petri dishes contained the other nutrients that bacteria need for growth, but $\mathrm{P}$ was supplied as a different molecule in each case. This means that, to grow in a certain petri dish, the bacteria needed to have the appropriate genes that helped them to use the specific source of $P$ that was added. If you look at Figure 3B, you can see two Petri dishes with different $P$ sources. The same bacterial were placed in both Petri dishes. Some bacteria could grow in both Petri dishes, but in some cases, bacteria could grow only in one dish, telling us that particular type of bacteria was not able to use both forms of $P$. We tested each of the 1,163 bacterial isolates with the six different $\mathrm{P}$-containing molecules. 
Figure 3

(A) In our experiment different $P$ sources were present in each Petri dish, to test the ability of different kinds of bacteria to use the $P$ contained in each source. In each Petri dish, bacteria of the same type were located at the same spot in the grid. (B) Example of the growth of the same bacteria in two different $P$ sources. The Petri dish on the left contained calcium phosphate and the dish on the right contained potassium phosphate as $P$ source. Arrows indicate the bacteria that could grow using only one of the two P sources. This means that to be able to use the $\mathrm{P}$ contained in each of these molecules, bacteria need different genes to carry out different processes.

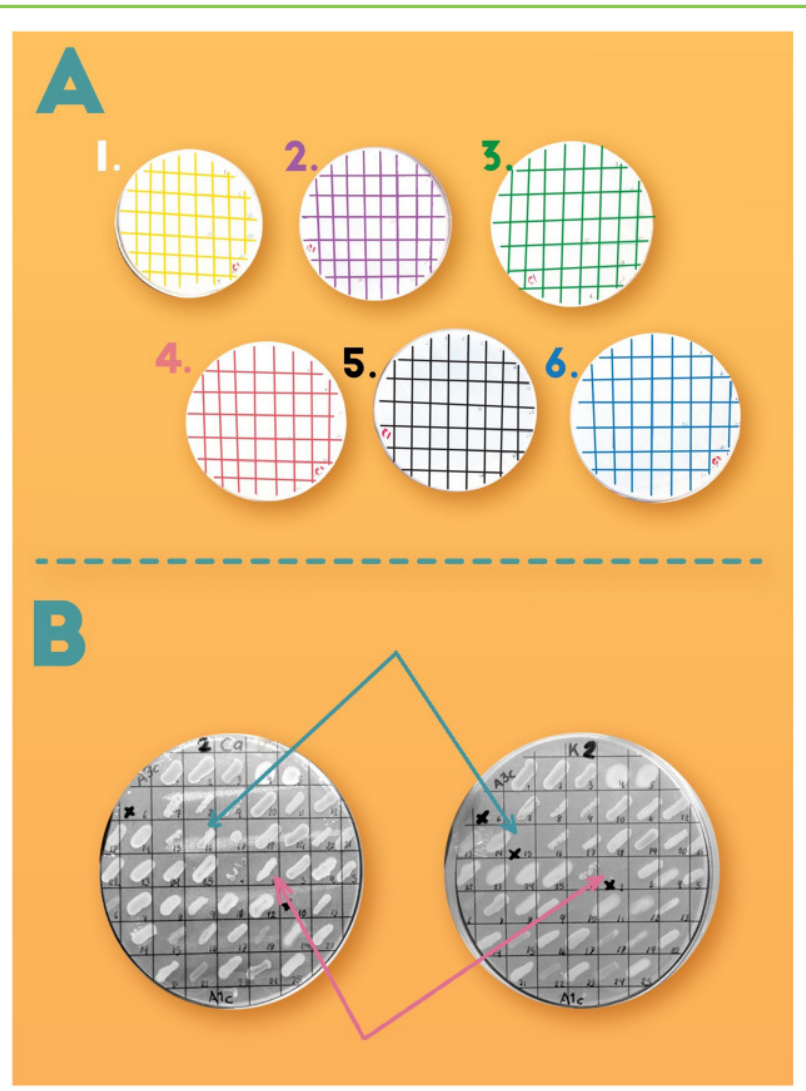

Figure 3

\section{WHAT DID WE LEARN FROM THESE P-HUNGRY BACTERIA?}

Rocks containing $\mathrm{P}$ are not equally distributed in ecosystems. Therefore, in extremely P-limited ecosystems, like the ecosystem from which these bacteria were isolated, bacteria can break down and use different forms of $\mathrm{P}$ to contribute to $\mathrm{P}$ cycling through the ecosystem. In these P-limited ecosystems, soil bacteria have been found to use many different strategies for using P. This is awesome: the less available $\mathrm{P}$ that bacteria have, the more powers they acquire for obtaining it.

As we can see, bacteria have many superpowers when it comes to the recycling of chemical elements. These bacteria make it possible for plants and animals to exist. These recycling processes have been at work for billions of years and they have been vital for the evolution of living beings on Earth.

\section{AUTHOR CONTRIBUTIONS}

YT-T conceived the study. All authors contributed to all aspects of the preparation and writing of the paper. All authors approved the final version. 


\section{ACKNOWLEDGMENTS}

The authors acknowledge the support of PAPIIT-DGAPA-UNAM grants (IA206219) and UNAM-DGAPAPAPIME grant (PE207418) and thank Fernanda Hernandez for her help with digital illustration.

\section{ORIGINAL SOURCE ARTICLE}

Tapia-Torres, Y., Rodríguez-Torres, M. D., Elser, J. J., Islas, A., Souza, V., García-Oliva, F., et al. 2016. How to live with phosphorus scarcity in soil and sediment: lessons from bacteria. Appl. Environ. Microbiol. 82:4652-62. doi: 10.1128/AEM.00160-16

SUBMITTED: 22 January 2019; ACCEPTED: 15 August 2019;

PUBLISHED ONLINE: 11 September 2019.

EDITED BY: Angelica Cibrian-Jaramillo, Center for Research and Advanced Studies (CINVESTAV), Mexico

CITATION: Tapia-Torres Y and Morón-Cruz A (2019) Bacteria Have Superpowers to Recycle Soil Nutrients. Front. Young Minds 7:116. doi: 10.3389/frym.2019. 00116

CONFLICT OF INTEREST: The authors declare that the research was conducted in the absence of any commercial or financial relationships that could be construed as a potential conflict of interest.

COPYRIGHT @ 2019 Tapia-Torres and Morón-Cruz. This is an open-access article distributed under the terms of the Creative Commons Attribution License (CC BY). The use, distribution or reproduction in other forums is permitted, provided the original author(s) and the copyright owner(s) are credited and that the original publication in this journal is cited, in accordance with accepted academic practice. No use, distribution or reproduction is permitted which does not comply with these terms.

\section{YOUNG REVIEWERS}

\section{ALAN, AGE: 13}

I am currently in the second year of high school. I am very observant, have a very good memory, and am interested in technology and videogames. I am also interested in maritime animals, and in the bacterial world. I would like to study medicine, because I am struck by the functioning of the human body and I want to help others. 

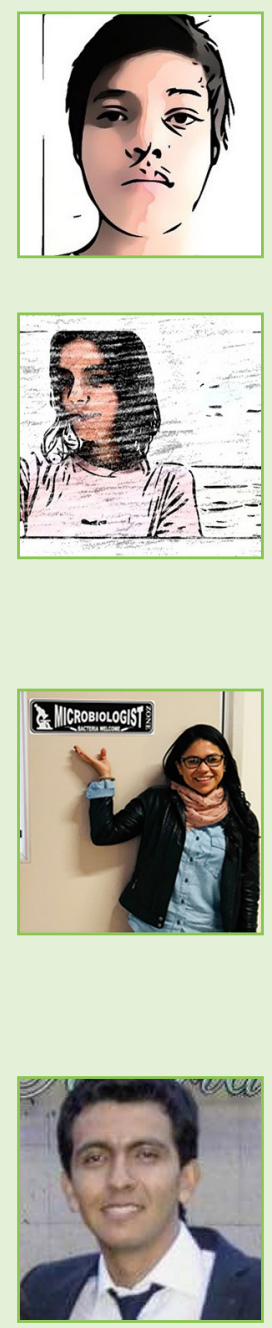

DIEGO, AGE: 14

My name is Diego but they call me "Morrillo," I am 14 years old and I study at the Cumbres de la Independencia school. I like to play videogames and walk. My favorite foods are tacos, chicken wings, and pizza.

\section{MANU, AGE: 14}

My name is Manuela but everyone calls me Manu I am in my second year of secondary school. I love horse riding and arts. When I grow up I would like to be a marine biologist or to study gastronomy.

\section{AUTHORS}

\section{YUNUEN TAPIA-TORRES}

Yunuen Tapia-Torres is a Soil Scientist who loves the complexity of the bacterial world. Her research at the Escuela Nacional de Estudios Superiores, Morelia, UNAM focuses on understanding the importance of bacteria on the transformation of molecules containing carbon, nitrogen and phosphorus in soil. She is working to strengthen research in the area of Soil Biogeochemistry in Mexico, and thereby guarantee fertile soil for the future. *ytapia@enesmorelia.unam.mx

\section{ALBERTO MORÓN-CRUZ}

Alberto Moron is a Biochemical Engineer and master's student of Sustainability Sciences at the Universidad Nacional Autónoma de México. He is interested in studying processes that lead to the efficient use of phosphorus; an element recognized as a non-renewable resource important for agricultural production, which is used inefficiently and irrationally in agricultural fields in Mexico. In view of this problem, Moron's objective is to evaluate the sustainability of the use of phosphorus in soils in order to obtain values of efficiency and economic yields. jamoron@cieco.unam.mx 